\title{
The Effect of Pegagan (Centella Asiatica (L.) Urban) Ethanol Extracts on Hippocampal PSD-95 Protein Expression in Male Wistar Rats
}

\author{
Adibah Ferhad1, Auliyani Andam Suri'1, Astri Handayani'1, Sri Redjeki2*, Ria Kodariah ${ }^{3}$ \\ ${ }^{1}$ Biomedical Science Graduate Study Program, Faculty of Medicine, Universitas Indonesia \\ ${ }^{2}$ Department of Physiology, Faculty of Medicine, Universitas Indonesia \\ ${ }^{3}$ Department of Anatomic Pathology, Faculty of Medicine, Universitas Indonesia
}

\begin{abstract}
One effort to overcome the decline in memory function is through herbal medicine. Pegagan (Centella asiatica (L.) Urban) contain the active components of triterpenoid and flavonoids, has been known to be able to improve memory function. Synaptic plasticity is the basis of memory formation which is strongly influenced by synapse proteins such as PSD-95. Loss of PSD-95 protein can cause memory function decline. This study aims to determine the effect of $70 \%$ ethanol extract of pegagan toward PSD-95 protein expression on hippocampus of male Wistar rat. Eighteen male Wistar rats were randomly divided into 3 groups, 6 rats/group: group (1) given ethanol extract of pegagan with dose $300 \mathrm{mg} / \mathrm{kgBW} /$ day (CA300), (2) given ethanol extract of pegagan with dose $600 \mathrm{mg} / \mathrm{kgBW} /$ day (CA600), and (3) control group (K), given daily aquadest. All three groups were treated for 28 consecutive days. At the end of the treatment period, rats were decapitated and the hippocampus was isolated from the brain. Analysis of protein was done by immunohistochemical method. Statistical analysis was performed by One Way ANOVA parametric test followed by Post-Hoc Bonferroni. The results showed that there was no significant difference between group $\mathrm{K}$ and group CA300 ( $\mathrm{P}=0.123)$, whereas there were significant differences between CA600 group and $\mathrm{K}$ group and $\mathrm{CA} 300$ group $(\mathrm{P}=0.000)$. From this research, it can be concluded that $70 \%$ ethanol extract of pegagan with dose $600 \mathrm{mg} / \mathrm{kgBW} /$ day can increase expression of PSD-95 protein on hippocampus of male Wistar rat.
\end{abstract}

Key words: Post Synaptic Density-95; memory function; flavonoids; Centella asiatica (L.) Urban.

\section{INTRODUCTION}

Aging is a natural biological process characterized by a decrease in physiological functions of the body including a decrease in memory function in the brain. (Shivarama Shetty and Sajikumar, 2017, Bettio et al., 2017) Decreasing memory function can occur in the normal aging process and in the aging process accompanied by degenerative diseases. (Bettio et al., 2017) Memory is the ability to record the life experiences so that affects a person's attitude or habit according to environmental conditions (Jared, 2010). The process of memory formation occurs through cellular mechanisms, namely the change in synapse strength called synapse plasticity (Lu et al., 2008, Leal et al., 2015). Plasticity at the excitatory synapse can be mediated at the level of pre-synapse and postsynapse (Leal et al., 2015). Postsynaptic density-95 (PSD-95) is the main scaffold protein in the postsynapse density at the excitatory synaptic glutamate. PSD-95 is a member of the membraneassociated guanylate kinase (MAGUK) (Zhang et al., 2013). PSD-95 plays a role in maintaining

\footnotetext{
*Corresponding author : Sri Redjeki

Email : djeki.pras@gmail.com
}

and modulating synapse strength (Chen et al., 2015). PSD-95 is often used as a marker of synapse at the post-synapse and is closely related to memory function (Nelson and Alkon, 2015). PSD95 plays a role in regulating post-synaptic receptors such as NMDA receptors and AMPA receptors.(Han and Kim, 2008) The long-term potentiation mechanism related to memory formation in the hippocampus is influenced by the delivery of AMPA receptors to the post-synapse membrane and this PSD-95 can control the number of AMPA receptors in the post-synapse membrane. (Ehrlich and Malinow, 2004) The loss of PSD-95 protein that occurs along with increasing age is closely related to a decrease in memory function (Ojo et al., 2012).

One of the effort to overcome the decrease in memory function is through herbal medication. Pegagan plant (Centella asiatica (L.) Urban) is a tropical medicinal plant from Apiaceae family originating from Southeast Asia including Indonesia. This pegagan leaf is edible, yellowish green, thin, with long petioles, and has a distinctive shape which is kidney-shaped, jagged, rounded, or oval-elliptical with seven leaf bones. These plants grow horizontally with reddish green stolon that 
merge each other and rooted underground (Orhan, 2012). Pegagan or antanan is often found in open places, on moist and fertile soil such as in rice fields, in grasslands, on the edge of trenches and on the roadside (Ramadhan et al., 2015). There are two main components in pegagan, namely triterpenoids and flavonoids. Both components function as antioxidants and are neuroprotective (Sari and Rochmah, 2015, Orhan, 2012, Vauzour et al., 2008). Pegagan has long been used in Ayurveda medicine and traditional Chinese medicine to improve memory function (Lokanathan et al., 2016). Previous research has shown that the distribution of ethanol extract of Centella asiatica for 8 weeks at a dose of $300 \mathrm{mg} / \mathrm{kg}$.BW increased the cognitive function of male Wistar rats aged 2 months.(Mirza I, 2013) It is not known whether this increase in cognitive function is related to proteins that underlie the memory formation.

The decrease memory function in humans occurs early in adulthood, that is, since the age of 20 (Marlatt et al., 2012). Therefore, this study was conducted to determine the effect of pegagan ethanol extract in increasing the expression of PSD-95 protein as a form of prevention of decrease memory function in hippocampus of Wistar male rats aged 6 months, where that age when converted to humans is equal to 18 (Andreollo et al., 2012).

\section{METHODOLOGY}

\section{Materials}

\section{Test drug materials}

Simplicia of pegagan plant (Centella asiatica (L.) Urban) obtained from Pusat Studi Biofarmaka Institut Pertanian Bogor (IPB). Extraction of the materials was conducted at Balai Penelitian Tanaman Rempah dan Obat (Balittro) Bogor. Pegagan is extracted with $70 \%$ ethanol using maceration method. After the materials are extracted, a qualitative test is conducted with the KLT method and quantitative test is conducted using the spectrophotometric method and TLC Scanner to find out the active materials of the pegagan ethanol extract. The design and method of this research have passed the ethical review by Komite Etik Penelitian Kesehatan Fakultas Kedokteran Universitas Indonesia with an ethical number: 824/UN2.FI/ETIK/2016.

\section{The subject of research}

The subjects of this study were experimental animals Wistar strain male rats (Rattus novergicus), 6 months old with an initial weight of 300 - 400 grams, healthy and active. The research subjects were obtained from BiofarmaBandung. The treatment of experimental animals was conducted at the Laboratorium Departemen Patologi Anatomi FKUI. Before and during the treatment, animal health was maintained so as not to get sick. Experimental animals are given standard food and drinks in ad libitum. The experimental animals is maintained in huskbottomed cages that are equipped with feed containers and drinking water bottles. The animal cages are kept clean and arranged 12 hours bright and 12 hours dark. The ambient temperature is maintained at $25+1^{\circ} \mathrm{C}$. Other things in the experiment were adjusted to the ethical code of commission for handling and using of experimental animals. The sample of this study was hippocampus tissue of male Wistar rats which was the subject of the research.

Materials and equipment for checking proteins

The procedure for examining the PSD-95 protein is conducted at Laboratorium Imunologi Departemen Patologi Anatomi FKUI using immunohistochemical methods (IHK). Materials and equipment used include xylene (Merck), ethanol (Merck) (with absolute concentration, 96\%, 80\% and 70\%), Phosphate Buffer Saline (PBS) (Biomatix) with a $\mathrm{pH}$ of 7.4 , sodium citrate buffer pH 6.0, Hydrogen peroxide (H202) 35\%, primary antibody anti-PSD95 (Abcam), secondary antibodies Universal HRP Polymer (Neopoly), detection kit (Biogear), Hematoxilin Meyer, saturated Lithium carbonate (5\%), entelan, super PAP pen (Biogear), and deionized water. While the equipment used include analytical scales, microtome, Aurona microscope slides (positively charged), cover glass, water bath, drying oven, slide warmer, Biocare's Decloaking Chamber, $\mathrm{pH}$ meter (Schoot), microscope (Olympus BX51) with a digital camera (Olympus).

\section{Method \\ Preparation of test drug materials}

The dried pegagan simplicia was extracted by maceration method at Balittro Bogor. $5 \mathrm{~kg}$ of dried pegagan simplicia is mashed using a grinder until it becomes powder. Pegagan powder was then weighed and obtained $4 \mathrm{~kg}$ of powder and then put into a stainless container and put in the solvent, $70 \%$ ethanol mixed with mixer for 3 hours. Subsequently precipitated over 24 hours. Thereafter filtered using filter paper. The filter results are concentrated by rotary evaporator at a temperature of $50^{\circ} \mathrm{C}$ until evaporation is complete. 326.4 gr thick extract was obtained and the rendement was $8.16 \%$ with a moisture content of $17.39 \%$.

After extraction, phytochemical tests were conducted using the KLT qualitative method and 
the results were obtained that pegagan extract contained alkaloids, saponins, tannins, phenolics, flavonoids, triterpenoids, steroids, and glycosides. Then proceed with a quantitative test to determine the percentage of active content of pegagan extract. Quantitative tests use spectrophotometric methods to determine tannin and flavonoids levels, which amounted to $0.22 \%$ and $0.44 \%$. Quantitative tests use TLC Scanner method to determine saponin levels and asiaticoside levels, which amounted to $1.25 \%$ and $0.65 \%$.

\section{The distribution of pegagan extract}

Experimental animals are weighed to determine the amount of extract to be given according to the dosage range. The preparation is prepared to fulfill the needs of the distribution extract. Dilution of the extract preparation was prepared for 7 days of treatment. This is conducted to avoid damage if the preparation is stored more than 7 days. After dilution, the preparation is stored in a refrigerator at $4^{\circ} \mathrm{C}$. After 7 days, preparations are made for the next day. Before being given to experimental animals, the preparation extract was left for a moment at room temperature, then stirred well so that it was mixed and there was no sediment to facilitate the rounding process in the experimental animals.

Experimental animals are divided randomly into three groups, namely: (1) the control group $(\mathrm{K})$ were given aquadest; (2) the group given the extract of pegagan with the dose of $300 \mathrm{mg} / \mathrm{kg}$. W/day (CA 300); (3) the group was given a pegagan extract with a dose of $600 \mathrm{mg} /$ kg.BW/day (CA 600). Each treatment towards every group was given once a day for 28 consecutive days at the same time in the morning, given orally using a stomach tube.

\section{Series of immunohistochemistry procedures and protein checks}

At the end of the treatment the research subjects were decapitated. Then the hippocampal tissue was isolated from the brain and put into $10 \%$ formalin buffer for 24 hours. Each treatment group was taken for each of the 6 hippocampal tissue from 6 experimental animals. Next, paraffin blocks were made and coronal directional slices were made with a thickness of 4 micrometers and floated in a water bath. Then the pieces are placed on coated slides. Liquids on the slides are dried, then the slides are put into drying oven for $30-60$ minutes with temperature $37^{\circ} \mathrm{C}$ (Spencer and Bancroft, 2008).

The CPI discharge procedure used in this study is the Neopoly IHC procedure which is the standard procedure for Biogear Polymer Neopoly
Detection Kit. From the optimization results obtained, optimal dilution for PSD-95 protein is a concentration of 1:500. After the CPI procedure is completed, the expression percentage measurement of PSD-95 protein is done by observing slides under a binocular light microscope (Olympus BX51) with 400x magnification and the image is taken with a builtin camera (Olympus) on the microscope. For each slide five images are taken representing five visual fields (2560x1920 pixels) in the CA1 area ofthe hippocampal tissue. The resulting images are calculated using ImageJ program with the IHC Profiler plug-in to produce intensity values automatically for each image. Then, the results are calculated using IHC Optical Density Score method.

The optical density data of the PSD-95 protein that has been obtained is then carried out with statistical analysis using SPSS 17.0 computer program. Data were analyzed using one way ANOVA test then Post-Hoc Bonferroni test with 95\% confidence level.

\section{RESULTS AND DISCUSSION}

One of the typical characteristics of aging is loss of memory function, especially in the hippocampus. This is related to changes in synapse morphology including loss of pre-synapse and post-synapse proteins, and progressive loss of synapse's density. (Ojo et al., 2012) The hippocampus is located at the edge of the temporal lobe of the cerebral cortex consisting of Cornu Ammonis and dentate gyrus. Cornu ammonis (CA) consists of four parts namely CA1, CA2, CA3 and CA4. But two important Cornu Ammonis are CA1 and CA3. CA1 consists of pyramidal cells and plays an important role in matching information obtained from CA3.(Anand and Dhikav, 2012, Bear et al., 2016) The development process of the human brain, including synapse density and synaptogenesis has started since inside the womb. Synaptogenesis is known to have occurred since the 34th week of pregnancy where nearly 40,000 new synapses are formed every second and continue until after birth, and begin to decline when entering adolescence period.(Tau and Peterson, 2010) Various studies also found that memory function began to decline after turning 20 years and goes on until 80 years old.(Marlatt et al., 2012) Based on that theory, the age of experimental animals is set at 6 months which is equivalent to 18 years in humans. The age determination for experimental animals is in accordance with the research objectives to find pegagan extract can be used as an action to prevent decreased memory function. 

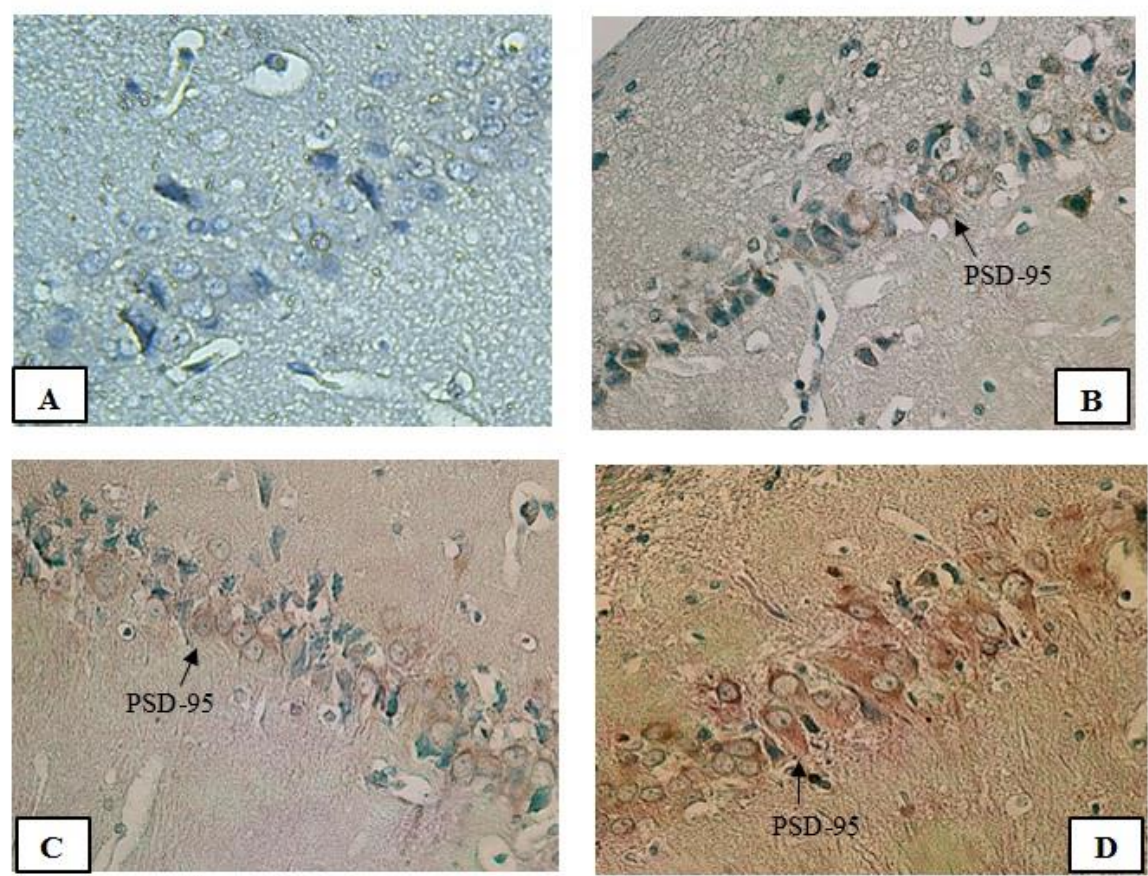

Figure 1. Revitalized PSD-95 CPI in the CA1 area of hippocampal tissue in male Wistar rats. A. negative control; B. control group; C. CA300 group; D. CA600 group. 400X magnification. (Arrow shows the expression of PSD-95 protein in hippocampus pyramidal cells that are browned in the pyramidal cell cytoplasm). Experimental animals were decapitated on the 29th day and the hippocampal tissues were isolated, then paraffin blocks were made and then cut to $4 \mu \mathrm{m}$. Recovering CPI is carried out with anti-PSD95 primary antibodies (Abcam), Universal HRP Polymer (Neopoly) secondary antibody.

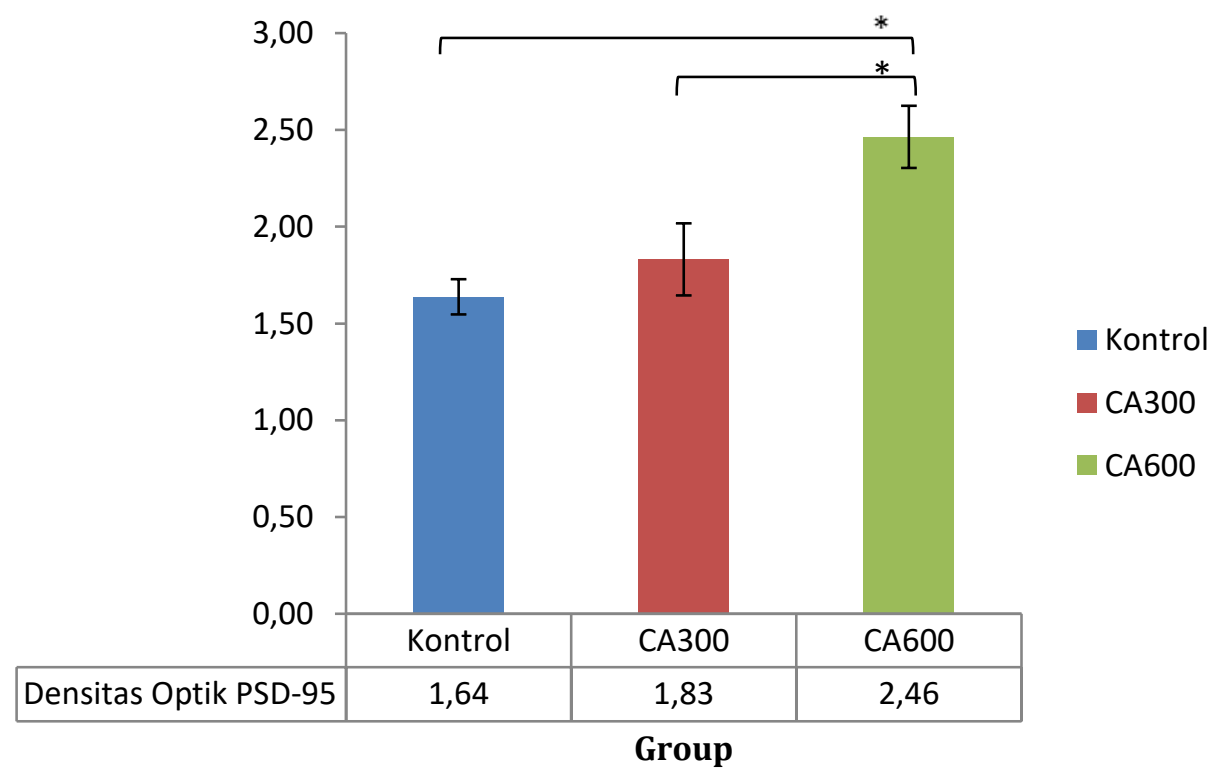

Figure 2. Comparison of mean values of optical density of PSD-95 proteins between the three groups. *The results of statistical analysis using the One Way Anova test followed by the Bonferroni Post-Hoc test; there was a significant difference between the CA600 group and the control group $(p=0.000)$ and CA300 $(p=$ 0.000 ). Significance $* p<0.05$. The data represent 6 experimental animals per group. Data in mean values, error bars show standard deviation (Remarks: Kolmogorov-Smirnov test results shows data is not normally distributed, but the transformation is successful). 
In this study, an examination of post synapse protein PSD-95 was examined in the hippocampal CA1 area of a male Wistar Rats. In Figure 1, the results of CPI output are shown on the sample network of control group, CA300, and CA600. Figure 1A shows a negative control where the expression of PSD-95 protein does not appear. Expression of PSD-95 protein in the CA1 region of male Wistar rats was seen to be the weakest in the control group (Figure 1B) and the strongest expression of PSD-95 protein was seen in the CA600 group (Figure 1D).

The mean optical density scores comparison between PSD-95 proteins in the three groups is shown in Figure 2. The highest mean value was found in the CA600 group (2.46 \pm 0.16$)$, followed by the CA300 group $(1.83 \pm 0.19)$ and the lowest was the control group $(1.64 \pm 0.09)$. Statistical analysis then carried out, with One Way Anova parametric test followed by Bonferroni Post-Hoc test. Based on the results of statistical analysis, it was found that there were significant differences between the CA600 group and the control group ( $p$ $=0.000)$ and CA300 group $(\mathrm{p}=0.000)$, while the CA300 group and the control group does not differ significantly $(\mathrm{p}=0.123)$.

The result of this study stated that administration of $70 \%$ pegagan ethanol extract can increase the expression of PSD-95 protein in the hippocampal CA1 area of male Wistar rats. The results of this study are supported by research which is conducted by Gray et al., that administration of pegagan extract in mice can increase the synaptic gene expression of PSD-95 in the hippocampus (Gray et al., 2016). Decision for giving 70\% ethanol extract is because $70 \%$ ethanol is best in dissolving asiaticosides contained in pegagan. (Salamah and Farahana, 2014)

Pegagan plant has many benefits including anti-inflammatory, antimicrobial, antifungal, antidepressant, antioxidant and anticancer properties (Lokanathan et al., 2016) as well as improving memory function and is neuroprotective (Orhan, 2012). The two main components in pegagan are triterpenoids and flavonoids. Triterpenoids consists of active components, namely asiatic acid and asiaticoside (Sari and Rochmah, 2015).

In this study it was stated that distributing the Pegagan ethanol extract containing asiaticoside for 28 consecutive days could increase the expression of PSD-95 in the male hippocampus of Wistar rats. The results of this study are supported by previous studies which stated that administration of asiaticoside for four consecutive weeks can increase the expression of PSD-95 in the hippocampus (Luo dkk., 2015).

\section{CONCLUSION}

The effect of giving pegagan ethanol extract (dose $600 \mathrm{mg} / \mathrm{kg} . \mathrm{BW}$ ) was better in increasing PSD-95 protein expression in the hippocampus of male Wistar rats compared to $300 \mathrm{mg} / \mathrm{kg}$.BW dose and the control group.

\section{ACKNOWLEDGEMENTS}

This research is supported through 2017 Thesis and Dissertation Scholarship by Lembaga Pengelola Dana Pendidikan (LPDP), Ministry of Finance of the Republic of Indonesia.

\section{REFERENCES}

Anand, K. S. \& Dhikav, V. 2012. Hippocampus in health and disease: An overview. Annals of Indian Academy of Neurology, 15, 239.

Andreollo, N. A., Santos, E. F. d., Araújo, M. R. \& Lopes, L. R. 2012. Rat's age versus human's age: what is the relationship? $A B C D$. Arquivos Brasileiros de Cirurgia Digestiva (São Paulo), 25, 49-51.

Bear, M. F., Connors, B. W. \& Paradiso, M. A. 2016. Neuroscience: Exploring the Brain., Philadelphia, Wolters Kluwer.

Bettio, L. E. B., Rajendran, L. \& Gil-Mohapel, J. 2017. The effects of aging in the hippocampus and cognitive decline. Neurosci Biobehav Rev, 79, 66-86.

Chen, X., Levy, J. M., Hou, A., Winters, C., Azzam, R., Sousa, A. A., Leapman, R. D., Nicoll, R. A. \& Reese, T. S. 2015. PSD-95 family MAGUKs are essential for anchoring AMPA and NMDA receptor complexes at the postsynaptic density. Proc Natl Acad Sci U S A, 112, E6983-92.

Ehrlich, I. \& Malinow, R. 2004. Postsynaptic density 95 controls AMPA receptor incorporation during long-term potentiation and experience-driven synaptic plasticity. $J$ Neurosci, 24, 916-27.

Gray, N. E., Harris, C. J., Quinn, J. F. \& Soumyanath, A. 2016. Centella asiatica modulates antioxidant and mitochondrial pathways and improves cognitive function in mice. $J$ Ethnopharmacol, 180, 78-86.

Han, K. \& Kim, E. 2008. Synaptic adhesion molecules and PSD-95. Prog Neurobiol, 84, 263-83.

Jared, S. R. 2010. Enhancement of memory in rats with Centella asiatica. Biomedical Research, 21.

Leal, G., Afonso, P. M., Salazar, I. L. \& Duarte, C. B. 2015. Regulation of hippocampal synaptic plasticity by BDNF. Brain Res, 1621, 82-101.

Lokanathan, Y., Omar, N., Puzi, N. N. A., Saim, A. \& Idrus, R. H. 2016. Recent updates in 
neuroprotective and neuroregenerative potential of Centella asiatica. The Malaysian journal of medical sciences: MJMS, 23, 4.

Lu, Y., Christian, K. \& Lu, B. 2008. BDNF: a key regulator for protein synthesis-dependent LTP and long-term memory? Neurobiol Learn Mem, 89, 312-23.

Luo, L., Liu, X. L., Mu, R. H., Wu, Y. J., Liu, B. B., Geng, D., Liu, Q. \& Yi, L. T. 2015. Hippocampal BDNF signaling restored with chronic asiaticoside treatment in depression-like mice. Brain Res Bull, 114, 62-9.

Marlatt, M. W., Potter, M. C., Lucassen, P. J. \& van Praag, H. 2012. Running throughout middleage improves memory function, hippocampal neurogenesis, and BDNF levels in female C57BL/6J mice. Dev Neurobiol, 72, 943-52.

Mirza I, R. H., Khomsan A, Marliyati SA, Damayanthi E, Winarto A. 2013. Pengaruh ekstrak etanol daun pegagan (centella asiatica (1.)

urban) terhadap gambaran darah, aktivitas,

dan fungsi kognitif tikus. Jurnal Kedokteran Hewan, 7.

Nelson, T. J. \& Alkon, D. L. 2015. Molecular regulation of synaptogenesis during associative learning and memory. Brain Res, 1621, 239-51.

Ojo, B., Rezaie, P., Gabbott, P. L., Davies, H., Colyer, F., Cowley, T. R., Lynch, M. \& Stewart, M. G. 2012. Age-related changes in the hippocampus (loss of synaptophysin and glial-synaptic interaction) are modified by systemic treatment with an NCAM-derived peptide, FGL. Brain Behav Immun, 26, 77888.

Orhan, I. E. 2012. Centella asiatica (L.) Urban: From Traditional Medicine to Modern Medicine with Neuroprotective Potential. Evid Based Complement Alternat Med, 2012, 946259.

Ramadhan, N. S., Rasyid, R. \& Syamsir, E. 2015. Daya Hambat Ekstrak Daun Pegagan (Centella asiatica) yang Diambil di Batusangkar terhadap Pertumbuhan Kuman Vibrio cholerae secara In Vitro. Jurnal Kesehatan Andalas, 4.

Salamah, N. \& Farahana, L. 2014. Uji Aktivitas Antioksidan Ekstrak Etanol Herba Pegagan (Centella asiatica (L.) Urb) dengan Metode Fosfomolibdat. Pharmaciana, 4.

Sari, D. C. R. \& Rochmah, M. A. 2015. The effects of ethanol extracts of centella asiatica leaf on serial serum brain derived neurotrophin factor (bdnf) concentration of rats (sprague dawley) following chronic stress. KnE Life Sciences, 2, 159.

Shivarama Shetty, M. \& Sajikumar, S. 2017. 'Tagging' along memories in aging: Synaptic tagging and capture mechanisms in the aged hippocampus. Ageing Res Rev, 35, 22-35.

Spencer, L. T. \& Bancroft, J. D. 2008. Microtomy: paraffin and frozen. Dalam: Brancroft JD, Gamble M. Theory and practice of histological techniques. 6th ed. Philadelphia: Elsevier.

Tau, G. Z. \& Peterson, B. S. 2010. Normal development of brain circuits. Neuropsychopharmacology, 35, 147-68.

Vauzour, D., Vafeiadou, K., Rodriguez-Mateos, A., Rendeiro, C. \& Spencer, J. P. 2008. The neuroprotective potential of flavonoids: a multiplicity of effects. Genes Nutr, 3, 115-26.

Zhang, J., Lewis, S. M., Kuhlman, B. \& Lee, A. L. 2013. Supertertiary structure of the MAGUK core from PSD-95. Structure, 21, 402-13. 